\title{
Age-dependent growth responses to climate from trees in Himalayan
}

\section{treeline}

\author{
Achyut Tiwari ${ }^{1 *}$ (i) \\ ${ }^{1}$ Central Department of Botany, Institute of Science and Technology, Tribhuvan University, Kirtipur Kathmandu, Nepal \\ "Correspondence: achyutone@gmail.com
}

Received: 19 July 2019 | Revised: 24 July 2020 | Accepted: 27 July 2020

\begin{abstract}
Tree rings provide an important biological archive for climate history in relation to the physiological mechanism of tree growth. Higher elevation forests including treelines are reliable indicators of climatic changes, and tree growth at most elevational treelines are sensitive to temperature at moist regions, while it is sensitive to moisture in semi-arid regions. However, there has been very less pieces of evidence regarding the age-related growth sensitivity of high mountain tree species. This study identified the key difference on the growth response of younger ( $<30$ years of age) and older ( $>30$ years) Abeis spectabilis trees from treeline ecotone of the Trans-Himalayan region in central Nepal. The adult trees showed a stronger positive correlation with precipitation (moisture) over juveniles giving the evidence of higher demand of water for adult trees, particularly in early growth seasons (March to May). The relationship between tree ring width indices and mean temperature was also different in juveniles and adult individuals, indicating that the juveniles are more sensitive to temperature whereas the adults are more sensitive to moisture availability. It is emphasized that the age-dependent growth response to climate has to be considered while analyzing the growth-climate relationship of high mountain tree populations.
\end{abstract}

Keywords: Abies spectabilis, Dendrochronology, Growth-climate response, Treeline, Tree ring

\section{1 | Introduction}

The high elevation natural treeline ecotones are highly sensitive to climate because the trees in these locations survive in a very narrow physiological threshold (Kullman 2002, Körner \& Paulsen 2004, Batllori \& Gutiérrez 2008). Upward shifts of high elevation treelines are generally expected in response to global warming (Kullman 2001, Holtmeier \& Broll 2007, Harsch et al. 2009), however, the interplay between precipitation pattern and warming temperature (Sigdel et al. 2018) as well as the biotic interaction (Liang et al. 2016) at higher elevation limit of trees are also critical factors for maintaining future treelines. Although the temperature is defined to be the critical climatic factor for tree growth and regeneration of tree species in treelines (Körner 2003, Holtmeier \& Broll 2007, Harsch et al. 2009), there are also strong pieces of evidence in which tree growth and treeline expansion are limited by insufficient moisture especially in case of semi-arid regions (Lloyd \& Fastie 2002, Wilmking et al. 2004, Wang et al. 2015, Sigdel et al. 2018). Hence, it is quite important to identify environmental factors associated with tree growth and treeline formation in higher elevation in order to predict the future of tree growth and treeline in a rapidly warming world (IPCC 2013).

Investigations of growth-climate response are quite critical to interpreting the response of forest growth and the dendroclimatic reconstructions (Tessier et al. 1997, Briffa et al. 1998). This also provides crucial information to assess future forest productivity, vegetation dynamics and tree species distributions (Thuiller et al. 2005, Tardif et al. 2006). The physiological mechanisms by which climatic parameters are translated into radial growth variations are complex because radial growth in any given year integrates the effects of climate conditions during and prior to growing season, local site conditions and physiological differences of tree species including the age of trees (Fritts 1976). In different biogeographic zones, changes in temperature, precipitation and radiation are known to limit tree growth in a different scale (Churkina \& Running 1998). However, at scale, local factors such as aspect, elevation, wind exposure, substrate condition, animal and human influence all can influence annual ring formation in trees. The radial growth of trees from high elevations mountains generally reflect temperature variations, whereas growth rates of 


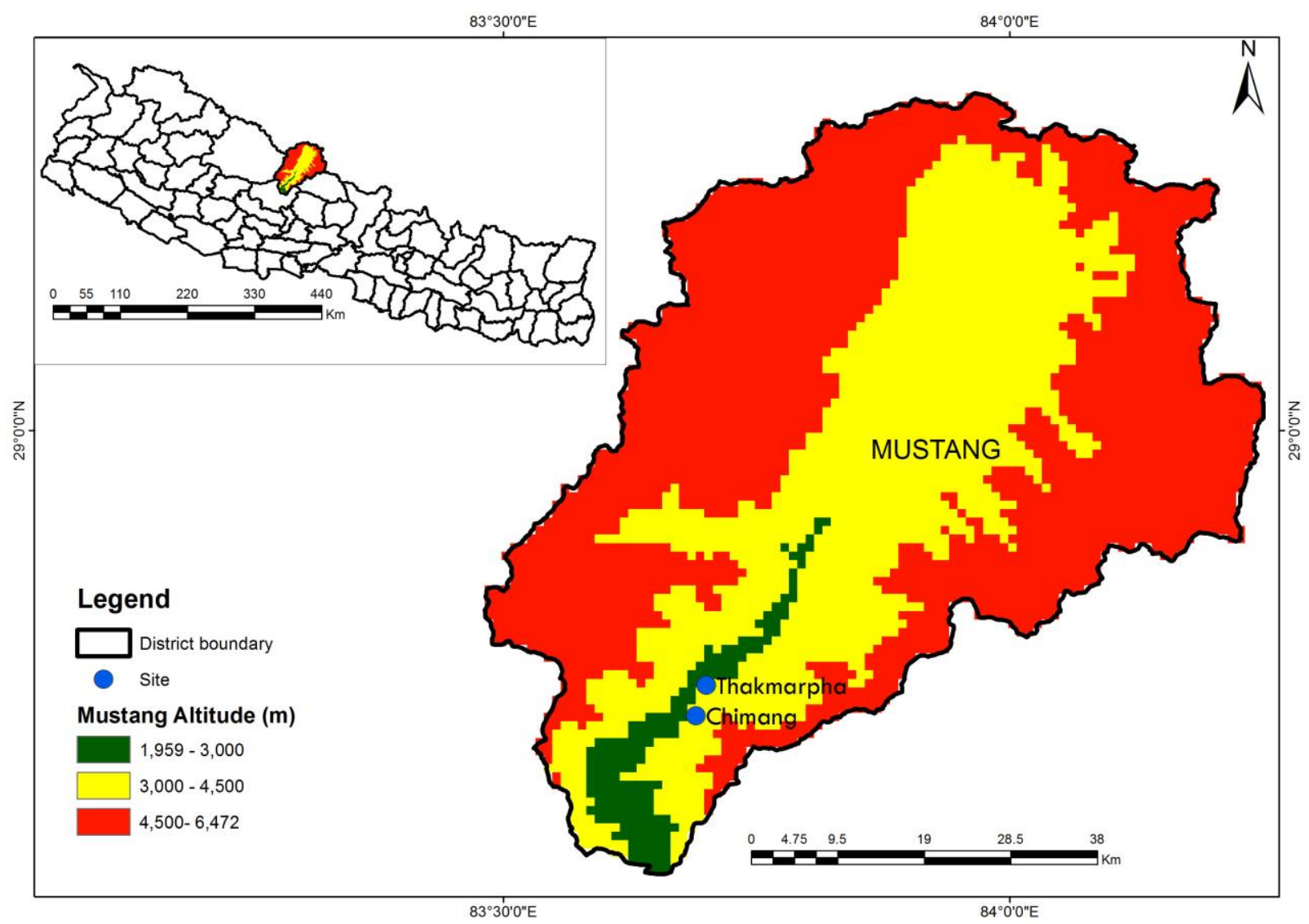

Figure 1. Location map of study area showing Abies spectabilis treeline site (Chimang) and climate station (Thakmarpha) in Mustang district, central Nepal.

trees from lower elevations generally reflect precipitation changes (La Marche 1974, Schweingruber 1996). Similarly, the temperature signal is stronger at temperature limited tree growth at the northern high latitudes (Briffa et al. 1998). However, because of the co-variation of various climatic parameters and complex plant physiological reactions and processes, attempts to define growth responses in terms of a single controlling factor

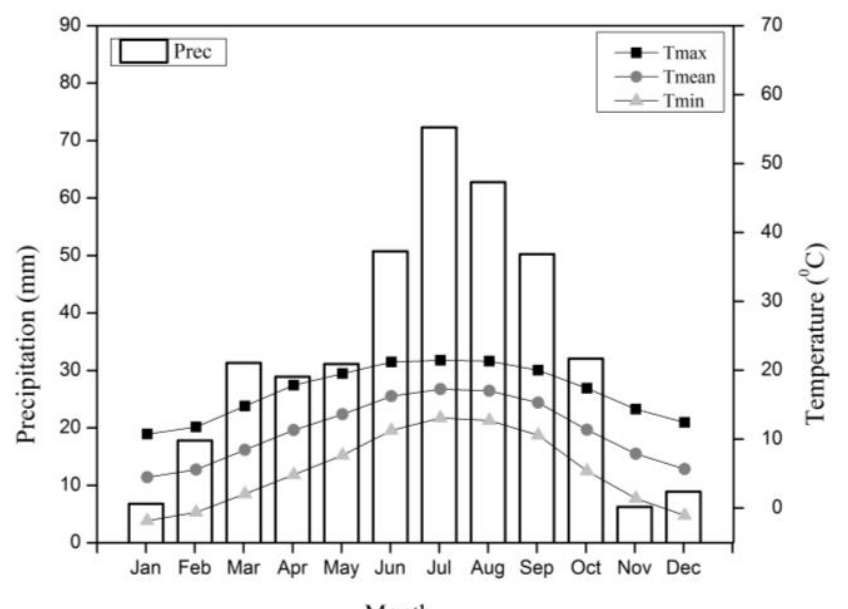

Figure 2. Climate summary of Thakmarpha climate station in Mustang district as the nearest climate station from Chimang treeline study site often fail (Fritts 1976). For example, during the relatively short period during summer, even at cold sites, water availability becomes the dominating factor for tree growth, once temperatures are high enough to allow any growth at all (Anfodillo et al. 1998, Carrer et al. 1998).

Age-dependent variation in growth climate relationship among juveniles and adult trees has been observed in many studies (Carrer \& Urbinati 2004), however the age group of trees showing the changing growth patterns with the same environmental factors is not adequately understood, particularly at treelines. With careful observation in age groups, this study attempted to divide trees from treeline ecotone in to two groups; juveniles ( $<30$ years age) and adults ( $>30$ years age), and analyzed the variation in growth climate response between them.

\section{2 | Materials and methods}

\section{1 | Study area}

The study was carried out at Chimang lekh $(28.720 \mathrm{~N}, 83.690 \mathrm{E}$, 3580-3641 m above sea level, asl) in the southern part of southwest facing slope of Mustang District in the Trans-Himalayan zone of central Nepal, within a rain shadow region (Fig. 1). Trans- 
Himalayan zone of central Nepal is located in the rain shadow of surrounding high mountains. Snow thaw is the main source of water for vegetation mainly during spring season (Aryal et al. 2012). The northern part of the Mustang lies in the Trans-Himalayan semi-arid dry zone, with the Tibetan-type highland being the driest zone of Nepal (Lomanthang: $200 \mathrm{~mm}$ annual rainfall) (Stainton 1972, Schickhoff 2005). A meteorological station is located nearby the study site $(<4 \mathrm{~km})$ (Thakmarpha; $28.75^{\circ} \mathrm{N}$, $83.7^{\circ} \mathrm{E}, 2566 \mathrm{~m}$ asl), with mean annual precipitation as $393 \mathrm{~mm}$ and mean annual temperature as $11.17^{\circ} \mathrm{C}$ (1970-2013) (Fig. 2).

\section{2 | Methods}

Field investigations were carried out during September of 2014. Sampling was conducted in an elevation transect on a topographically uniform area of sub alpine treeline ecotone. The ecotone includes the uppermost distribution limit (species limit) of $A$. spectabilis (irrespective of age) and the uppermost timberline. Tree cores were extracted from both juvenile ( $<30$ years of age) and adult trees ( $>30$ years of age) at the treeline ecotone. Ring width were measured at a resolution of $0.01 \mathrm{~mm}$ with a LINTAB II measuring system (Rinntech, Germany), following standard dendrochronological techniques (Fritts 1976). Tree ring width chronologies were separately produced from juvenile and adult trees. Growth-climate relationship was observed by comparing climatic response (monthly total precipitation and mean temperature) with tree ring indices of juvenile and adult trees separately, the growth limiting climatic factor was examined by using Pearson's correlations.

\section{3 | Results}

Two standard tree ring-width chronolgies; 68 years using 40 tree cores from 36 trees and 30 years using 30 tree cores from 20 trees at (Fig. 3a, b) were produced from treeline ecotone (3439$3638 \mathrm{~m}$ asl). The results indicated that both juvenile and adult tree ring width fluctuated through times, although the trend is not significantly developed. The chronology statistics are presented in Table 1.

Table 1. Tree-ring chronology summary statistics

\begin{tabular}{|l|l|l|l|l|l|l|}
\hline Chronology & $\begin{array}{l}\text { Chronology length } \\
\text { (years) }\end{array}$ & Trees (cores) & $\begin{array}{l}\text { Mean } \\
\text { sensitivity }\end{array}$ & EPS & $\begin{array}{l}\text { Series } \\
\text { intercorrelation }\end{array}$ & $\begin{array}{l}\mathbf{1}^{\text {st }} \text { order } \\
\text { autocorrelation }\end{array}$ \\
\hline Adult trees & 68 & $36(40)$ & 0.326 & 0.931 & 0.472 & 0.612 \\
\hline Juvenile trees & 30 & $30(20)$ & $0.29^{*}$ & $0.639^{*}$ & $0.89^{*}$ & 0.446 \\
\hline
\end{tabular}

Note: *The lower values (mean sensitivity and expressed population signal (EPS); in juvenile chronology is probably due to higher fluctuation in growth. Because the juvenile trees $(<30$ years of age) usually show high variation in growth rate as they are more sensitive to microhabitat, thereafter challenging crossdating process among trees. 


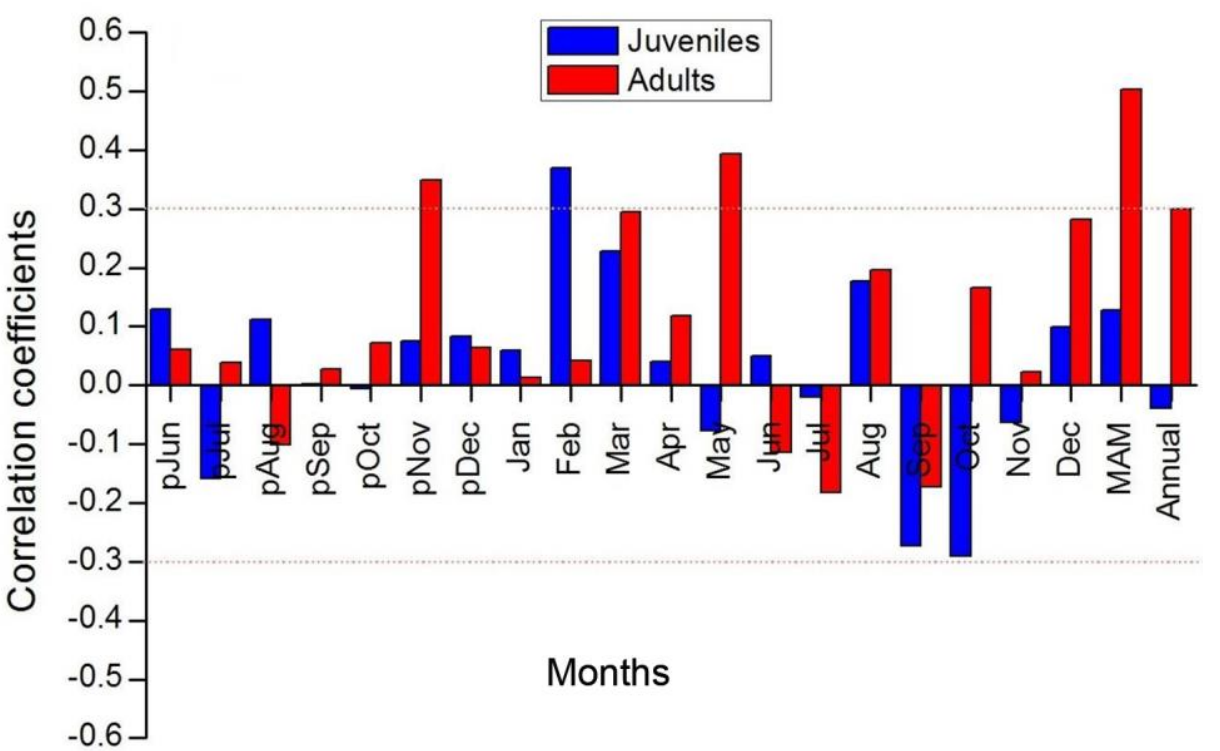

Figure 4. Correlation coefficients between radial growth of $A$. spectabilis and total monthly rainfall of June in the previous year to October of the current year spring (March-May), annual and summer months; the dashed horizontal lines indicate significant correlation at $95 \%$ confidence level for two-tailed test.

Positive correlation was observed between winter rainfall and tree radial growth $(r=0.36)$ for juvenile trees. Similarly, radial growth of adult trees and rainfall of previous year's November $(r=0.36)$, May ( $r=0.4)$, spring season (March-May) $(r=0.5)$ and annual rainfall $(r=0.3)$ also showed positive association. It was found that previous year November mean temperature had significant positive correlation with radial growth $(r=0.42)$ of juvenile trees (Fig. 4). However significant negative correlation was observed

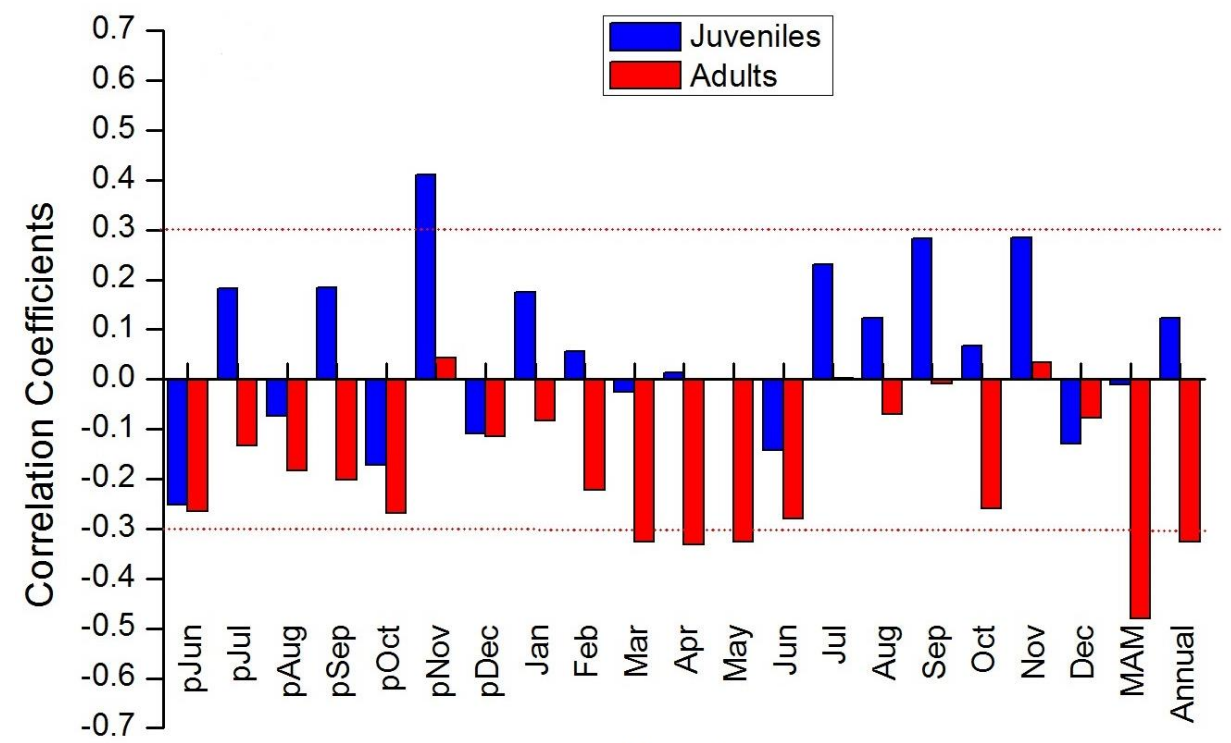

Months

Figure 5. Correlation coefficients between radial growth of $A$. spectabilis and mean monthly temperature of June in the previous year to October of the current year spring (March-May), annual and summer months; the dashed horizontal lines indicate significant correlation at $95 \%$ confidence level for two-tailed test. between radial growth and mean temperature (Tmean) of March $(r$ $=-0.32)$, April $(r=-0.33)$, May $(r$ $=-0.32$ ), spring season (MarchMay) $(r=-0.48)$ and for annual rainfall $(r=-0.32)$ (Fig. 5).

\section{4 | Discussion}

The results indicated that the strength of correlation between radial growth and total precipitation showed distinctly different signals in juvenile and adult tree populations. The adults showed stronger positive response with precipitation (moisture) over juveniles giving the first indication of higher demand of water for adult trees (Fig. 4), particularly in early growth seasons (March to May). The radial growth showed positive correlation with mean temperature of few months (significant with previous year's September) (Fig. 5). Hence it is found that the correlation strength between radial growth and rainfall is decreased from adults to juveniles, whereas the correlation strength between radial growth and mean temperature showed increasing trend from adults to juveniles.

Dominant mature trees are usually analyzed in climate-growth response studies in order to minimize non-climatic signals due to competition (Fritts 1976). Ecophysiological studies indicate that functional processes such as photosynthetic performance and water use efficiency usually change with tree age (Mencuccini et al. 2005, Rossi et al. 2008). Tree age is also known to modulate sensitivity of radial tree growth to climate (Szeicz \& MacDonald 1994, Mérian \& Lebourgeois 2011), whereby older trees being more sensitive to growth limiting climate factors than younger/ smaller trees. Some 
studies have also explained that growth-climate response of conifers is modulated by tree-size (De Luis et al. 2009), as the process ageing is associated with the increase in size which is in turn related to functional processes occurring in trees (Mencuccini et al. 2005).

The evidences of age-related growth response of trees to climatic conditions is an important physiological mechanism, however there exist a gap in knowledge for considering trees as juveniles and adult ones in terms of their physiological capabilities. The higher moisture sensitivity at timberline forest than treeline was attributed to higher temperature and increased competition between trees in comparison to less dense trees at treeline (LV \& Zhang 2012, Qi et al. 2015, Tiwari et al. 2017) in case of shifting treelines that are represented by younger tree population over timberline that are dominated by adult tree population. In most of the studies of treeline dynamics, the recent densification of forest stands has been observed in the upper limit of their distribution, although there is no higher rate of upward shifting of treelines (Liang et al. 2011, Tiwari et al. 2017). Such evidences also indicated that young trees would be more benefited by warming temperature over adult trees. In this context, our findings of distinct growth response of juveniles and adult trees from the same treeline ecotone, could be an interesting discourse of physiological differences in different age group of trees. It is emphasized that the dendrochronological perspective and physiological perspective of tree growth should be analysed separately and more carefully in order to improve our understanding on physiological mechanism of tree growth, especially in climate sensitive areas such as sub-alpine treelines. Hence, it would be highly critical to classify age group of trees while capturing robust growth response of trees to climatic factors.

\section{Conclusions}

The difference in age-dependent growth response to climate was worked out by using the annually formed growth rings in Abies spectabilis trees of treeline from semi-arid regions of TransHimalayan region of Mustang district. The study reported that the adult trees showed stronger positive correlation with precipitation (moisture) over juveniles giving the indication of higher demand of water for adult trees, particularly in early growth seasons (March to May). And there was difference in correlation strength between ring width indices with mean temperature between juvenile and adult individuals. It further indicated that the juveniles are more sensitive to temperature whereas the adults are more sensitive to moisture supply. However more cases with multiple species should be analyzed to gain more confidence in such predictions.

\section{Acknowledgements}

The author would like to acknowledge Xishuangbanna Tropical Botanical Garden, Chinese Academy of Sciences for providing research opportunity. Mr. Raju Bista, Mr. Krishna Prasad Sharma are acknowledged for their great help in sample collection. Further, representatives of Chimang Community Forest and $\mathrm{Mr}$ Indra Thakali of Chimang are also acknowledged for their kind cooperation during field work.

\section{Conflicts of interest}

Author declares no conflict of interest.

\section{ORCID}

Achyut Tiwari (D) https://orcid.org/0000-0001-9095-4067

\section{References}

Anfodillo, T., Rento, S., Carraro, V., Furlanetto, L., Urbinati, C. and Carrer, M. 1998. Tree water relations and climatic variations at the alpine timberline: seasonal changes of sap flux and xylem water potential in Larix decidua Miller, Picea abies (L.) Karst and Pinus cembra (L.). Annals of Forest Science 155:159-172.

Aryal, A., Hipkins, J., Ji, W., Raubeinhimer, D. and Brunton, D. 2012. Distribution and diet of brown bear in Annapurna Conservation Area, Nepal. Ursus 23:231-236.

Batllori, E. and Gutiérrez, E. 2008. Regional tree line dynamics in response to global change in the Pyrenees. Journal of Ecology 96:1275-1288.

Briffa, K. R., Schweingruber, F. H., Jones, P. D., Osborn, T. J., Shiyatov, S. G. and Vaganov, E. A. 1998. Reduced sensitivity of recent treegrowth to temperature at high northern latitudes. Nature 39:678-682.

Carrer, M. and Urbinati, C. 2004. Age-dependent tree ring growth responses to climate in Larix decidua and Pinus Cembrea. Ecology 85(3):730-740.

Carrer, M., Anfodillo, T., Urbinati, C., Carraro, V. 1998. High-altitude forest sensitivity to global warming: results from long-term and short-term analyses in the eastern Italian Alps. In: Beniston, M. and Innes, J. L. (Eds.) The impacts of climate variability of forest. Springer-Verlag, Berlin, Heidelberg, pp 171-189.

Churkina, G., Running, S. W. 1998. Contrasting climatic controls on the estimated productivity of global terrestrial biomes. Ecosystems 1(2):206-215. 
De Luis, M., Novak, K., Cufar, K. and Raventos, J. 2009. Size mediated climate-growth relationships in Pinus halepensis and Pinus pinea. Trees 23:1065-1073. https://doi.org/10.1007/s00468-009-0349-5

Fritts, H. C. 1976. (Reprint, 2001) Tree rings and climate. The Blackburn Press, Caldwell, New Jersey.

Harsch, M. A., Hulme, P. E., McGlone, M. S. and Duncan, R. P. 2009. Are treelines advancing? A global meta-analysis of treeline response to climate warming. Ecology Letters 12:1040-1049. https://doi.org/10.1111/j.1461-0248.2009.01355.x

Holtmeier, F. K. and Broll, G., 2007. Treeline advance - driving processes and adverse factors. Landscape Online 1:1-33. https://doi.org/10.3097/LO.200701

IPCC. 2013. Summary for policymakers. In: Stocker, T. F., Qin, D., Plattner, G. K., Tignor, M., Allen, S. K., Boschung, J., Nauels, A., Xia, Y., Bex, V., Midgley, P. M, (Eds.) Climate Change 2013: The physical science basis. Contribution of Working Group I to the Fifth Assessment Report of the Intergovernmental Panel on climate change. Cambridge University Press, Cambridge, pp 3-32.

Körner, C. 2003. Alpine plant life: functional plant ecology of high mountain ecosystems. Springer, Berlin, Germany.

Körner, C. and Paulsen, J. 2004. A world-wide study of high altitude treeline temperatures. Journal of Biogeography 31:713-732. https://doi.org/10.1111/j.1365-2699.2003.01043.x

Kullman, L. 2001. 20th century climate warming and tree-limit rise in the Southern Scandes of Sweden. Ambio 30:72-80 https://doi.org/10.1579/0044-7447-30.2.72

Kullman, L. 2002. Rapid recent range-margin rise of tree and shrub species in the Swedish Scandes. Journal of Ecology 90:68-77. https://doi.org/10.1046/j.0022-0477.2001.00630.x

La Marche, V. C. 1974. Paleoclimatic inferences from long tree-ring records. Science 183:1043-1048.

Liang, E., Wang, Y., Eckstein, D. and Luo, T. 2011. Little change in the fir tree-line position on the southeastern Tibetan Plateau after 200years of warming. New Phytologist 190:760-769 https://doi.org/10.1111/j.1469-8137.2010.03623.x

Liang, E., Wang, Y., Piao, S., Lu, X., Camarero, J. J., Zhu, H., Zhu, L. et al. 2016. Species interactions slow warming-induced upward shifts of treelines on the Tibetan Plateau. Proceedings of the National Academy of Sciences of the United States of America 113:43804385. https://doi.org/10.1073/pnas.1520582113

Lloyd, A. H. and Fastie, C. L. 2002. Spatial and temporal variability in the growth and climate response of treeline trees in alaska. Climatic Change 52:481-509. https://doi.org/10.1023/A:1
Lv, L. X. and Zhang Q. B. 2012. Asynchronous recruitment history of Abies spectabilis along an altitudinal gradient in the Mt. Everest region. Journal of Plant Ecology 5:147-156. https://doi.org/10.1093/jpe/rtr016

Mencuccini, M., Martínez-Vilalta, J., Vanderklein, D., Hamid, H. A., Korakaki, E., Lee, S. et al. 2005. Sizemediated ageing reduces vigour in trees. Ecology Letters 200(8):1183-1190. https://doi.org/10.1111/j.1461-0248.2005.00819.x

Mérian, P. and Lebourgeois, F. 2011. Size-mediated climate-growth relationships in temperate forests: A multispecies analysis. Forest Ecology and Management 261:1382-1391. https://doi.org/10.1016/j.foreco.2011.01.019

Qi, Z., Liu, H., Wu, X. and Hao, Q. 2015. Climate-driven speedup of alpine treeline forest growth in the Tianshan Mountains, Northwestern China. Global Change Biology 21:816-826. https://doi.org/10.1111/gcb.12703

Rossi, S., Deslauriers, A., Anfodillo, T. and Carrer, M. 2008. Age-dependent xylogenesis in timberline conifers. New Phytologist 177:199-208. https://doi.org/10.1111/j.1469-8137.2007.02235.x

Schickhoff, U. 2005. The upper timberline in the Himalayas, Hindu Kush and Karakorum: a review of geographical and ecological aspects. In Broll, G. and Keplin, B., (Eds.) Mountain ecosystems: studies in treeline ecology. Springer, Berlin, Germany, 275-354.

Schweingruber, F. H. 1996. Tree rings and environment dendroecology. Haupt, Bern, p 609.

Sigdel, S. R., Wang, Y., Camarero, J., Zhu, H., Liang, E. and Peñuelas, J. 2018. Moisture-mediated responsiveness of treeline shifts to global warming in the Himalayas. Global Change Biology 24(11):55495559. https://doi.org/10.1111/gcb.14428

Stainton, J. D. A. 1972. Forests of Nepal. Haffner Press, New York

Szeicz, J. M. and MacDonald, G. M. 1994. Age dependent tree ring growth responses of subarctic white spruce to climate. Canadian Journal of Forestry Research 24:120-132.

Tardif, J. C., Conciatori, F., Nantel, P. and Gagnon, D. 2006. Radial growth and climate responses of white oak (Quercus alba) and northern red oak (Quercus rubra) at the northern distribution limit of white oak in Quebec, Canada. Journal of Biogeography 33:1657-1669. https://doi.org/10.1111/j.1365-2699.2006.01541.x

Tessier, L., Guibal, F., Schweingruber and F. H. 1997. Research strategies in dendroecology and dendroclimatology in mountain environments. Climatic Change 36:499-517.

Thuiller, W., Lavorel, S., Araujo, M. B., Sykes, M. T. and Prentice, I. C. 2005. Climate change threats to plant diversity in Europe. Proceedings of the National Academy of Sciences of the United 
States of America 102:8245-8250. https://doi.org/10.1073/pnas.0409902102

Tiwari, A., Fan, Z.-X., Jump, A.S., Li, S.-F. and Zhou, Z.-K. 2017. Gradual expansion of moisture sensitive Abies spectabilis forest in the TransHimalayan zone of central Nepal associated with dimate change. Dendrochronologia 41:34-43. https://doi.org/10.1016/j.dendro.2016.01.006

Wang, Y., Liang, E., Ellison, A. M., Lu, X. and Camarero, J. J. 2015. Facilitation stabilizes moisture-controlled alpine juniper shrublines in the central Tibetan Plateau. Global and Planetary Change 132:2030. https://doi.org/10.1016/j.gloplacha.2015.-06.007

Wilmking, M., Juday, G. P., Barber, V. A. and Zald H. S. J. 2004. Recent climate warming forces contrasting growth responses of white spruce at treeline in Alaska through temperature thresholds. Global Change Biology 10:1724-1736. https://doi.org/10.1111/j.13652486.2004.00826.x

\section{Cite this article as:}

Tiwari, A. 2020. Age-dependent growth responses to climate from trees in Himalayan treeline. Nepalese Journal of Zoology 4(1):16-22. https://doi.org/10.3126/njz.v4i1.30669 